\title{
Effects of processed recycled poultry bedding with tannins extracted from pomegranate peel on the nutrient digestibility and growth performance of lambs
}

\author{
A. Sharifi ${ }^{1} \&$ M. Chaji $i^{1 \#}$ \\ Department of Animal Science, Agricultural Sciences and Natural Resources University of Khuzestan, Molasani, Ahvaz, \\ Iran
}

(Received 13 June 2018; Accepted 17 February 2019; First published online 13 April 2019)

\author{
Copyright resides with the authors in terms of the Creative Commons Attribution 4.0 South African Licence. \\ See: http://creativecommons.org/licenses/by/4.0/za \\ Condition of use: The user may copy, distribute, transmit and adapt the work, but must recognise the authors and \\ the South African Journal of Animal Science.
}

\begin{abstract}
The aim of this experiment was to decrease the rumen degradability rate of recycled poultry bedding (RPB) protein using pomegranate peel extract (PPE) as the tannin source. Furthermore, to study the effects of this processing method on nutrient digestibility, rumen and blood parameters, nitrogen retention, growth performance, carcass characteristics of male Arabi lambs, and the economic value of diets and production. Thirty-two Arabi lambs (19.7 $\pm 2.45 \mathrm{~kg}$ bodyweight, $90 \pm 12$ days old) were randomly assigned to one of four dietary treatments including a control and RPB treated with $20 \%, 25 \%$ and $30 \%$ PPE on a dry matter basis. Compared with the control, treatment of RPB with PPE did not affect apparent digestibility of dry matter, organic matter, neutral detergent fibre or acid detergent fibre. However, apparent crude protein digestibility decreased significantly. Dietary treatments had no effect on ruminal $\mathrm{pH}$, although ammonia-nitrogen and blood urea nitrogen concentration decreased in diets containing RPB treated with PPE. All lambs were in a positive nitrogen balance and the highest nitrogen retention was observed in the dietary group that was fed RPB treated with $25 \%$ PPE. Adding PPE to RPB up to $25 \%$ significantly increased final bodyweight, total gain, average daily gain and warm carcass weight, and improved the economic values of production as it decreased the price of each kilogram diet and cost per unit of production (each kilogram bodyweight). The dry matter intake and gain efficiency were unaffected by treatments. Therefore, treatment of RPB with $25 \%$ PPE in the finishing diets of Arabi lambs improved growth performance and nitrogen metabolism without affecting feed intake and gain efficiency, and warm carcass weight, and improved the economic values of production.
\end{abstract}

Keywords: ammonia nitrogen, blood urea nitrogen, carcass characteristics, economic analysis, nitrogen balance

\# Corresponding author: chaji@ramin.ac.ir

\section{Introduction}

Limitations imposed by reducing animal feed and water resources in several developing countries have increased livestock production costs. However, using agro-industrial by-products such as recycled poultry bedding (RPB) is generally considered one means to overcome this problem under certain circumstances (Azizi-Shotorkhoft et al., 2012).

In Iran, the production of dry RPB exceeds 1.5 million metric tons annually (Statistical Centre of Iran, 2013). RPB is a solid waste from the floor of poultry houses, particularly broiler houses, which contains the original bedding material, spilled feed, feathers and excreta. It has a favourable chemical composition, that is, high crude protein (CP), which ranges from 150 to $350 \mathrm{~g} / \mathrm{kg}$ dry matter (DM), high mineral content (Rankins et al., 2002), and high DM digestibility (650 - $680 \mathrm{~g} / \mathrm{kg} \mathrm{DM}$, Mavimbela \& Van Ryssen, 2001), suggesting that RPB has the potential to be a ruminant feedstuff. However, owing to the presence of pathogenic bacteria it must be processed before it is fed to ruminant animals (Rankins et al., 2002). Crude protein in RPB is present in two forms, namely true protein (TP) and non-protein N (NPN), of which TP accounts for the greater proportion (549 $\mathrm{g} / \mathrm{kg} \mathrm{DM}$ ) (Azizi-Shotorkhoft et al., 2012). Most of the NPN of RPB is uric acid, which undergoes rapid degradation in the rumen (Animut et al., 2002). 
Common protein supplements are not metabolized efficiently (i.e. hydrolysed to ammonia-nitrogen) in the rumen, resulting in decreased efficiency and utilization of protein metabolism and consequently animal performance (Tamminga \& Hobson, 1996). Processing dietary protein to protect it from rumen microbial degradation without sacrificing nitrogen $(\mathrm{N})$ requirements for microbial growth increases the flow of amino acids to the duodenum (Jolazadeh et al., 2015). This can lead to an improvement in protein utilization, and potentially increased muscle deposition (Abarghuei et al., 2014).

Studies have shown beneficial effects of plant secondary metabolites (PSM) such as tannins on ruminal fermentation parameters and reduction of ruminal degradation of CP (Alipour \& Rouzbehan, 2010; Jolazadeh et al., 2015). Additionally, Min et al. (2003) found that dietary tannins at a level of $20-45 \mathrm{~g} / \mathrm{kg}$ dietary DM improved average daily gain (ADG) in steers that grazed winter wheat. However, in the study of Dentinho et al. (2007), treatment of soybean meal with tannin extracted from Citrus ladanifer decreased its effective rumen degradability and in vitro intestinal protein digestibility at low doses (i.e., $12.5,25$ and $50 \mathrm{~g}$ total phenol $/ \mathrm{kg}$ ). Responses to dietary tannin supplementation are variable, and depend on the type, source and amount of tannin, the basal diet and the animal receiving the supplementation (Patra \& Saxena, 2011).

Pomegranate peel is produced by extracting the juice from pomegranates and these by-products are produced in Iran at approximately 120000 metric tons annually (Mirzaei-Aghsaghali et al., 2011). The product contains several PSMs, such as saponin, polyphenolic compounds, primarily punicalagin and ellaggi tannins (Mirzaei-Aghsaghali et al., 2011). In most cases, PSM extraction uses costly solvents such as methanol, ethanol and acetone (Makkar, 2003), but water is inexpensive and easy to handle at farm level. Therefore, the objectives of the present study were to assess the effects of reducing the degradability rate of RPB as an inexpensive supplemental protein in rumen with various levels of PPE on nutrient digestion, rumen parameters, performance, and economical value of diets and meat production in finishing lambs.

\section{Materials and Methods}

All experimental procedures were conducted according to The Care and Use of Agricultural Animals in Research and Teaching (FASS, 2010) guidelines. All procedures and guidelines involving animals were approved by the Animal Experiment Committee at Khuzestan Agricultural Sciences and Natural Resources University.

The RPB was collected from commercial broiler farms and prepared at the main factory in Sabzevar, Iran. To remove pathogenic bacteria and improve its quality, the material was humidified up to $23 \%$ and then thermally processed by indirect vapour pressure at $75-85^{\circ} \mathrm{C}$ for $20 \mathrm{~min}$. The thermal processing method had a favourable effect on decreasing pathogenic bacteria in RPB, as it decreased the total population of pathogenic bacteria, Escherichia coli and Salmonella, significantly (Badiee Baghsiah, 2011).

Two metric tons of pomegranate peel were obtained from the factory in Baghmalek (Khuzestan Province, Iran), which used similar varieties and processing methods. A two-step extraction process was performed according to the procedure of Capparucci et al. (2011). In the first step, sun-dried pomegranate peel was ground through a $0.5 \mathrm{~mm}$ screen and soaked in water at a ratio of $1: 10(\mathrm{w} / \mathrm{v})$ for 24 hours.

Table 1 Chemical composition ( $\mathrm{g} / \mathrm{kg} \mathrm{DM}$ ) of recycled poultry bedding and pomegranate peel extract

\begin{tabular}{lccccc}
\hline & PPE & \multicolumn{5}{c}{ Diets (level of treated RPB) } \\
\cline { 3 - 6 } & & $\mathbf{0}$ & $\mathbf{2 0}$ & $\mathbf{2 5}$ & $\mathbf{3 0}$ \\
\hline \multirow{2}{*}{ Dry matter } & 875 & 900 & 885 & 884 & 879 \\
Crude protein & 203 & 224 & 209 & 207 & 202 \\
Neutral detergent fibre & 75.0 & 350 & 291 & 289 & 288 \\
Acid detergent fibre & 57.5 & 195 & 175 & 173 & 170 \\
Ash & 253 & 147 & 164 & 167 & 169 \\
Total phenolic & 151 & 0 & 30.2 & 37.8 & 45.5 \\
Total tannins & 111 & 0 & 22.2 & 27.8 & 33.5 \\
\hline
\end{tabular}

RPB: recycled poultry bedding

PPE: pomegranate peel extract

RPB treated with PPE at the levels of $0 \%$ (control), $20 \%, 25 \%$ and $30 \%$ of DM

${ }^{1}$ Non-protein nitrogen (NPN) content of RPB was $402 \mathrm{~g} / \mathrm{kg}$ total nitrogen 
In the second step, the aqueous pomegranate peel was filtered and boiled to yield PPE. RPB was treated with PPE at levels of $0 \%, 20 \%, 25 \%$ and $30 \%$ of DM. The chemical compositions of RPB, PPE and RPB that were treated with various levels of PPE are presented in Table 1.

Total phenolics and total tannin measurements were as described by Makkar (2000). Total phenol was determined using Folin-Ciocalteu's reagents, and the concentration was measured as tannic acid equivalent using tannic acid (Merck, Munich, Germany) as standard. Total tannins were measured as described by Makkar (2000).

Thirty-two male fat-tailed Arabi lambs (19.7 $\pm 2.45 \mathrm{~kg}$ bodyweight) at $90 \pm 12$ days old were randomly assigned to the four dietary groups using a completely randomized design (eight lambs per dietary treatment). The animals were housed individually in concrete floor pens $(1.3 \times 1.2 \mathrm{~m})$ in a closed shed. All animals were allowed an adaptation period of 14 days, followed by a data collection period of 64 days (total 78 days). The initial 14 days were regarded as adaptation of the animals to the experimental diets, individual pens and experimental conditions. During the adaptation period, the amount of RPB that was treated with various levels of PPE was gradually increased in the diet offered to each animal to reach the levels regarded as the experimental levels in the dietary treatments. At the start of the adaptation period, all animals were treated for parasites, namely external parasites (1 mL Azantole 10\% per $7 \mathrm{~L}$ of water, as spraying method) (Bayer AG, Barmen, Leverkusen, Germany) and internal parasites (Phelonil, mixture of $50 \mathrm{mg}$ triclabendazole and $5.37 \mathrm{mg}$ levamisole hydrochloride per $\mathrm{mL}, 12 \mathrm{~mL}$ per lamb) (Darou-Pakhsh Co., Iran) and were vaccinated against enterotoxaemia (3 $\mathrm{mL}$ enterotoxaemia vaccine per lamb) (Razi Vaccine and Serum Research Institute, Iran).

Table 2 Ingredients and chemical composition ( $\mathrm{g} / \mathrm{kg}$ DM or as stated) of the experimental diets containing recycled poultry bedding treated with different levels of pomegranate peel extract

\begin{tabular}{|c|c|c|c|c|}
\hline & \multicolumn{4}{|c|}{ Diets (level of treated RPB) ${ }^{1}$} \\
\hline & 0 & 20 & 25 & 30 \\
\hline \multicolumn{5}{|l|}{ Ingredients, g/kg DM } \\
\hline Alfalfa hay & 150 & 150 & 150 & 150 \\
\hline Wheat straw & 50 & 50 & 50 & 50 \\
\hline Corn silage & 50 & 50 & 50 & 50 \\
\hline Treated RPB & 180 & 180 & 180 & 180 \\
\hline Soybean meal & 40 & 40 & 40 & 40 \\
\hline Corn grain, ground & 169 & 169 & 169 & 169 \\
\hline Barley, ground & 250 & 250 & 250 & 250 \\
\hline Wheat bran & 100 & 100 & 100 & 100 \\
\hline Urea & 2.0 & 2.0 & 2.0 & 2.0 \\
\hline Salt & 2.5 & 2.5 & 2.5 & 2.5 \\
\hline Magnesium oxide & 1.0 & 1.0 & 1.0 & 1.0 \\
\hline Sodium bicarbonate & 2.0 & 2.0 & 2.0 & 2.0 \\
\hline Minerals and vitamins & 3.0 & 3.0 & 3.0 & 3.0 \\
\hline \multicolumn{5}{|c|}{ Nutrient composition, $\mathrm{g} / \mathrm{kg} \mathrm{DM}$ or as stated } \\
\hline Dry matter & 878 & 877 & 875 & 872 \\
\hline Organic matter & 813 & 812 & 810 & 808 \\
\hline Crude protein & 157 & 153 & 151 & 149 \\
\hline Neutral detergent fibre & 304 & 300 & 293 & 290 \\
\hline Acid detergent fibre & 167 & 164 & 162 & 160 \\
\hline Lignin (sa) & 29.6 & 27.0 & 26.9 & 26.7 \\
\hline Metabolizable energy (Mcal/kg DM) & 2.51 & 2.49 & 2.48 & 2.47 \\
\hline
\end{tabular}

RPB: recycled poultry bedding

${ }^{1}$ RPB treated with pomegranate peel extract at the levels of $0 \%$ (control), $20 \%, 25 \%$ and $30 \%$ of DM 
Four iso-energetic and iso-nitrogenous diets (Table 2) containing RPB (18\% of DM) that was treated with different levels of PPE $(0 \%, 20 \%, 25 \%$ and $30 \%$ of DM) were formulated to meet the nutrient requirements of growing lambs at 3 - 6 months old with a growth rate of $250 \mathrm{~g} /$ day and a dry matter intake (DMI) of $1300 \mathrm{~g} /$ day (NRC, 2007).

The levels of PPE in the present study were selected from the authors' in vitro screening experiment by supplementing RPB with different levels of PPE (0\%, 5\%, 10\%, 15\%, 20\%, 25\%, 30\% and 35\%) of dietary DM (Sharifi et al., 2017)). The experimental diets did not differ in types and proportions of ingredients, except for RPB, which was treated with different levels of PPE. The diets, which were fed as a total mixed ration (TMR), were offered to the lambs ad libitum twice daily at 8:00 and 17:00 to ensure a level of 5\% orts (AziziShotorkhoft et al., 2015).

Feed consumption and orts were recorded daily during the experiment to determine DMI. The moisture contents of corn silage and TMR were determined weekly and used to make ration adjustments. Samples of TMR and refusals were collected weekly and stored at $-20{ }^{\circ} \mathrm{C}$ until analyses. All lambs were weighed individually at the beginning and end of the experiment and at 16-day intervals before the 8:00 feeding, after 16 hours of feed deprivation. For each lamb, ADG was calculated by linear regression analysis of bodyweight versus time. Gain efficiency was calculated as g ADG per daily DMI (g).

To measure nutrient digestibility and $\mathrm{N}$ balance, all lambs were transferred to individual metabolism cages on day 43 of the trial. After a seven-day adaptation period, samples of feeds and faeces that had been collected over six days, were weighed, and a 10\% representative sample was frozen for subsequent analysis. Total apparent digestibility of DM, organic matter (OM), crude fibre (CP), neutral detergent fibre (NDF) and acid detergent fibre (ADF) was measured using the total faecal collection method (Givens et al. 2000). During the collection period, urine was collected in buckets containing $100 \mathrm{~mL}$ of sulphuric acid $\left(\mathrm{H}_{2} \mathrm{SO}_{4}, 10 \% \mathrm{v} / \mathrm{v}\right)$, and urine samples $(100 \mathrm{~mL})$ were stored at $-4{ }^{\circ} \mathrm{C}$. At the end of the collection period, an aliquot of the urine samples was sampled and analysed for total urinary $\mathrm{N}$.

At the end of the experiment, all animals were weighed after 16 hours of feed deprivation and dispatched by exsanguination using conventional humane procedures (Azizi-Shotorkhoft et al., 2015). After complete bleeding, the animals were skinned, and external organs (skin, head and feet) were separated and weighed. All carcasses were eviscerated and internal organs or tissues, including the heart, liver, kidneys, spleen, lungs, kidney-pelvic-gut fat (internal fat) and digestive tract, were separated and weighed. Empty bodyweight was obtained by subtracting the weight of the digestive contents from harvest weight. Lamb carcases were weighed and halved carefully. Then, the right sides were cut into six wholesale cuts, namely neck, shoulder, brisket, loin, legs and fat tail, and weighed separately (Kyanzad, 2001). Back-fat thickness of the left side of carcasses was measured over the deepest part of the loin-eye muscle.

For economic evaluation of the experiment, the efficiency of production (return on investment and cost per unit production) was obtained using these equations (Anderson et al., 2005):

Return on investment $=$ income/expenses

Cost per unit production $=$ expenses/produce

Return on investment per lamb was calculated as income from the sale of $1 \mathrm{~kg}$ live weight gain divided by cost of feed for $1 \mathrm{~kg}$ of live weight gain. For individual lambs, the cost per unit production was computed as the cost of feed offered for total bodyweight gain (as US dollar) divided by total bodyweight gain (kg).

Rumen liquor samples $(40-50 \mathrm{~mL})$ were taken via stomach tube from all lambs on day 54 of the trial three hours after the morning feeding. The first 10 to $20 \mathrm{~mL}$ rumen liquor collected from each lamb was discarded to limit saliva contamination (Jasmin et al., 2011) and pH was measured immediately after sampling. Thereafter, the samples were strained through three layers of muslin before $5 \mathrm{~mL}$ was collected into $1 \mathrm{~mL} 0.2 \mathrm{~N} \mathrm{HCl}$ to stop fermentation, after which they were transported to the laboratory and frozen $\left(-20{ }^{\circ} \mathrm{C}\right)$ for ammonia analysis. On day 55 of the experiment, blood samples were taken from all lambs by jugular venipuncture into vacutainers containing lithium heparinate, three hours after the morning feeding,. Plasma was obtained by centrifugation at $1500 \times \mathrm{g}$ for $20 \mathrm{~min}$ and frozen at $-20{ }^{\circ} \mathrm{C}$ for subsequent analysis.

The RPB, PPE, experimental diets, orts and faeces were oven-dried at $55^{\circ} \mathrm{C}$, and ground to pass through a 1-mm sieve (Wiley mill, Swedesboro, USA). Dry matter, ash, $\mathrm{N}$ and ether extract were analysed according to AOAC (2005) procedures 930.15, 924.05, 984.13 and 954.02, respectively. Neutral detergent fibre was determined without using sodium sulphite and amylase treatment, and was corrected for residual ash (Van Soest et al., 1991). Acid detergent fibre was determined and corrected for residual ash (\# 973.18) (AOAC, 1990). Lignin (sa) was determined by solubilizing cellulose with $720 \mathrm{~g} / \mathrm{kg}$ sulphuric acid (Robertson \& Van Soest (981). After thawing, rumen liquor was analysed for ammonia-N according to Broderick \& Kang (1980). Plasma metabolites, including glucose, triglycerides, urea, blood urea-N (BUN), total protein and 
albumin, were determined by spectrophotometry (Jenway, Genova, UK) using kits manufactured by Pars Azmun Diagnostics (Tehran, Iran).

A balanced completely randomized design was used to determine the effect of RPB treated with various levels of PPE on different parameters. Data were analysed by the general linear model (GLM) procedures of SAS (SAS Institute, 2001), based on the statistical model:

$$
Y_{i j}=\mu+T_{i}+e_{i j}
$$

where: $Y_{i j}$ is observation (digestibility, ruminal parameters and blood biochemical metabolites, $\mathrm{N}$ balance, and growth performance),

$\mu$ is the general mean

$T_{i}$ is the effect of different levels of PPE

$\mathrm{e}_{\mathrm{ij}}$ is the standard error of means

The performance data were adjusted using initial bodyweight as a covariate. Differences among means were tested using the Duncan method.

\section{Results}

Treatment of RPB with PPE did not affect $(P>0.05)$ the apparent digestibility of DM, OM, NDF and ADF (Table 3). However, apparent CP digestibility in the diets containing PPE decreased $(P<0.05)$ relative to the control treatment.

Table 3 Effect of feeding recycled poultry bedding treated with different levels of pomegranate peel extract on apparent nutrient digestibility in male Arabi lambs

\begin{tabular}{|c|c|c|c|c|c|c|}
\hline & \multicolumn{4}{|c|}{ Level of treated RPB $^{1}$} & \multirow{2}{*}{ SEM } & \multirow{2}{*}{$P$-value } \\
\hline & 0 & 20 & 25 & 30 & & \\
\hline \multicolumn{7}{|l|}{ Apparent digestibility, \% } \\
\hline Dry matter & 78.6 & 79.2 & 80.1 & 77.9 & 0.89 & 0.12 \\
\hline Organic matter & 79.5 & 80.1 & 81.7 & 79.4 & 0.82 & 0.27 \\
\hline Crude protein & $82.0^{a}$ & $80.0^{\mathrm{b}}$ & $79.7^{\mathrm{b}}$ & $78.7^{b}$ & 0.48 & $<0.01$ \\
\hline Neutral detergent fibre & 72.7 & 73.1 & 73.2 & 71.7 & 1.11 & 0.62 \\
\hline Acid detergent fibre & 69.2 & 69.1 & 70.5 & 68.4 & 1.44 & 0.63 \\
\hline
\end{tabular}

RPB: recycled poultry bedding

${ }^{1}$ RPB treated with pomegranate peel extract at the levels of $0 \%$ (control), $20 \%, 25 \%$, and $30 \%$ of DM SEM, standard error of mean

a,b Means within a row with different superscripts differ significantly $(P<0.05)$

Dietary treatments had no effect $(P>0.05)$ on ruminal $\mathrm{pH}$, although ammonia- $\mathrm{N}$ concentration in the diets containing RPB treated with PPE decreased $(P<0.05)$ compared with the control (Table 4). Plasma urea and BUN decreased $(P<0.05)$ in lambs that were fed diets that contained RPB treated with PPE. The lowest concentrations were observed in PRB that was treated with the highest level of PPE (i.e., 30\% of DM) (Table 4) relative to RPB that was free of PPE. Other plasma biochemical metabolites such as glucose, triglycerides, albumin and total protein did not differ $(P>0.05)$ among the experimental lambs.

Nitrogen intake and $N$ excreted via faeces were not affected by feeding PRB treated with PPE (Table 5 ), but total $\mathrm{N}$ excretion and $\mathrm{N}$ excreted via urine were reduced $(P<0.05)$. All lambs were in positive $\mathrm{N}$ balance and the highest and lowest $(P<0.05) \mathrm{N}$ retention was observed in lambs fed RPB treated with $25 \%$ and $30 \%$ PPE, respectively. 
Table 4 Effect of feeding recycled poultry bedding treated with different levels of pomegranate peel extract on ruminal parameters and blood metabolites of male Arabi lambs

\begin{tabular}{|c|c|c|c|c|c|c|}
\hline & \multicolumn{4}{|c|}{ Level of treated RPB ${ }^{1}$} & \multirow{2}{*}{ SEM } & \multirow{2}{*}{$P$-value } \\
\hline & 0 & 20 & 25 & 30 & & \\
\hline \multicolumn{7}{|l|}{ Ruminal parameters } \\
\hline $\mathrm{pH}$ & 6.22 & 6.27 & 6.33 & 6.40 & 0.130 & 0.77 \\
\hline Ammonia nitrogen, $\mathrm{mg} / 100 \mathrm{~mL}$ & $17.6^{\mathrm{a}}$ & $16.1^{\mathrm{ab}}$ & $15.3^{\mathrm{b}}$ & $14.4^{\mathrm{b}}$ & 0.58 & 0.02 \\
\hline \multicolumn{7}{|l|}{ Blood parameters, mg/100 mL } \\
\hline Glucose & 60.2 & 62.4 & 61.6 & 59.2 & 1.56 & 0.53 \\
\hline Triglyceride & 38.3 & 38.8 & 40.9 & 38.7 & 0.55 & 0.18 \\
\hline Urea & $11.0^{\mathrm{a}}$ & $9.7^{\mathrm{ab}}$ & $8.8^{\mathrm{b}}$ & $8.5^{\mathrm{b}}$ & 0.51 & 0.02 \\
\hline Blood urea nitrogen & $5.08^{\mathrm{a}}$ & $4.41^{\mathrm{ab}}$ & $3.96^{\mathrm{b}}$ & $3.90^{\mathrm{b}}$ & 0.230 & 0.02 \\
\hline Total protein & 8.9 & 7.8 & 8.1 & 8.2 & 0.39 & 0.48 \\
\hline Albumin & 5.28 & 5.39 & 5.06 & 5.09 & 0.250 & 0.75 \\
\hline
\end{tabular}

RPB: recycled poultry bedding

${ }^{1}$ RPB treated with pomegranate peel extract at the levels of $0 \%$ (control), $20 \%, 25 \%$, and $30 \%$ of DM

SEM, standard error of mean

a,b Means within a row with different superscripts differ significantly $(P<0.05)$

Table 5 Effect of feeding recycled poultry bedding treated with different levels of pomegranate peel extract on nitrogen balance of male Arabi lambs

\begin{tabular}{|c|c|c|c|c|c|c|}
\hline & \multicolumn{4}{|c|}{ Level of treated RPB ${ }^{1}$} & \multirow{2}{*}{ SEM } & \multirow{2}{*}{$P$-value } \\
\hline & 0 & 20 & 25 & 30 & & \\
\hline Nitrogen $(\mathrm{N})$ intake, g/day & 32.8 & 31.5 & 32.7 & 30.5 & 0.60 & 0.10 \\
\hline Faecal N excreted, g/day & 10.3 & 10.5 & 10.7 & 11.5 & 0.32 & 0.12 \\
\hline Urinary N excreted, g/day & $12.9^{\mathrm{a}}$ & $11.5^{\mathrm{b}}$ & $10.5^{c}$ & $10.2^{\mathrm{C}}$ & 0.23 & $<0.01$ \\
\hline Total N excreted, g/day & $23.3^{\mathrm{a}}$ & $21.9^{\mathrm{ab}}$ & $21.1^{\mathrm{b}}$ & $21.7^{\mathrm{b}}$ & 0.42 & 0.04 \\
\hline Retained N, g/day & $9.5^{\mathrm{ab}}$ & $9.6^{\mathrm{ab}}$ & $11.7^{\mathrm{a}}$ & $8.9^{b}$ & 0.55 & 0.04 \\
\hline Retained N, g/kg BW & $0.29^{b}$ & $0.28^{\mathrm{bc}}$ & $0.32^{\mathrm{a}}$ & $0.27^{c}$ & 0.004 & $<0.01$ \\
\hline Retained N, g/kg BW ${ }^{0.75}$ & $0.69^{b}$ & $0.68^{b}$ & $0.79^{\mathrm{a}}$ & $0.65^{c}$ & 0.006 & $<0.01$ \\
\hline
\end{tabular}

RPB: recycled poultry bedding

${ }^{1}$ RPB treated with pomegranate peel extract at the levels of $0 \%$ (control), $20 \%, 25 \%$ and $30 \%$ of DM

SEM, standard error of mean

$a, b, c$ Means within a row with different superscripts differ significantly $(P<0.05)$

The highest $(P<0.05)$ final bodyweight, total gain and ADG were observed in RPB treated with $25 \%$ PPE compared with the control RPB (Table 6). However, DMI and GE were not affected $(P>0.05)$ by the inclusion level of PPE in RPB.

The highest $(P<0.05)$ warm carcass weight $(\mathrm{HCW})$ was observed in RPB treated with 25\% PPE, relative to lambs fed other rations (Table 7). However, empty bodyweight, dressing percentage, digestive contents, empty digestive tract, empty rumen and back-fat thickness and weights of neck, shoulder, brisket, loin, leg and fat tail were not affected $(P>0.05)$ by feeding RPB treated with various levels of PPE. Weights of carcass cuts (i.e. neck, shoulder, brisket, loin, legs and fat-tail) and offal parts (i.e., skin, head, feet, internal fat, liver, heart, kidneys, lung and spleen) were also unaffected $(P>0.05)$. 
Table 6 Effect of feeding recycled poultry bedding treated with different levels of pomegranate peel extract on growth performance of male Arabi lambs

\begin{tabular}{lccccccc}
\hline & \multicolumn{9}{c}{ Level of treated RPB $^{\mathbf{1}}$} & \multirow{2}{*}{ SEM } & P-value \\
\cline { 2 - 5 } & $\mathbf{0}$ & $\mathbf{2 0}$ & $\mathbf{2 5}$ & $\mathbf{3 0}$ & & \\
\hline Initial bodyweight, $\mathrm{kg}$ & 19.6 & 20.3 & 20.0 & 19.0 & 0.56 & 0.7 \\
Final bodyweight, kg & $33.3^{\mathrm{b}}$ & $34.3^{\mathrm{b}}$ & $36.5^{\mathrm{a}}$ & $32.9^{\mathrm{b}}$ & 1.11 & 0.04 \\
Total gain, kg & $13.7^{\mathrm{b}}$ & $14.0^{\mathrm{b}}$ & $16.5^{\mathrm{a}}$ & $13.9^{\mathrm{b}}$ & 1.01 & 0.05 \\
Dry matter intake, kg/day & 1.3 & 1.3 & 1.4 & 1.3 & 0.12 & 0.59 \\
Average daily gain, g/day $^{\text {Feed efficiency }}$ & $214^{\mathrm{b}}$ & $219^{\mathrm{b}}$ & $255^{\mathrm{a}}$ & $218^{\mathrm{b}}$ & 10.9 & 0.04 \\
& 0.16 & 0.17 & 0.19 & 0.17 & 0.014 & 0.23 \\
\hline
\end{tabular}

RPB: recycled poultry bedding

${ }^{1}$ RPB treated with pomegranate peel extract at the levels of $0 \%$ (control), 20\%, 25\%, and 30\% of DM

${ }^{2}$ Ratio of average daily gain $(\mathrm{g})$ to dry matter intake $(\mathrm{g})$

SEM, standard error of mean

${ }^{a, b}$ Means within a row with different superscripts differ significantly $(P<0.05)$

The highest and lowest returns on investment (Table 8) were obtained in diets containing $25 \%$ and $20 \%$ tannin extract $(P<0.05)$. The highest and lowest costs per unit production were obtained in diets containing $20 \%$ and $25 \%$ tannin extract $(P<0.05)$.

\section{Discussion}

In the present study, similar nutrient digestibility (i.e. DM, OM, NDF and ADF) from PPE-treated RPB inclusion in the diet was probably because in the experimental diets, the concentration of tannins was below the level at which their detrimental effects on rumen microbes are observed. Generally, condensed tannins at a level greater than $55 \mathrm{~g} / \mathrm{kg}$ diet DM have negative effects on nutrient digestibility (Min et al., 2003). According to McAllister et al. (1994), condensed tannins bind to dietary compounds or rumen bacteria, decrease bacterial attachment to feed particles, and consequently decrease nutrient digestibility. Consistent with the current results, Jolazadeh et al. (2015) reported that treatment of soybean meal with various levels of pistachio extract concentrate to Holstein bulls did not affect nutrient digestibility.

The reduction of CP digestibility by treatment of RBP with PPE was possibly due to a binding effect of the both true protein (TP) and non-protein N (NPN) contents of RPB with PPE (Dschaak et al., 2011), thereby protecting them from ruminal proteolysis (Jolazadeh et al., 2015). In agreement with these observations, Harley et al. (2017) reported that hydrolysable tannins might reduce the digestibility of nutrients (i.e. carbohydrates and minerals), particularly proteins. Rahimi et al. (2014) also indicated that supplementing Balochi lamb diets with pistachio hulls decreased the digestibility of CP. Variations in digestibility among studies that used PSM as feed additives may relate to the concentration and chemical composition of the metabolites, and the plant source (Jolazadeh et al., 2015).

In all lambs in the present study, mean ruminal $\mathrm{pH}$ values were within the normal physiological range (Dschaak et al., 2011). Different responses (i.e. increase, decrease or without effect) on ruminal pH by supplementing ruminant diets with tannins have been reported (Dschaak et al., 2011). Ruminal ammonia-N concentration in all experimental lambs was higher than the minimum level (i.e. $5 \mathrm{mg} / \mathrm{dL}$ ) required to support optimum rumen microbial growth (Griswold et al., 2003). The decreased ruminal ammonia-N concentration observed when feeding RPB treated with PPE could be explained by the formation of tannin-protein complexes in the rumen, which probably resulted in a reduced degradation of ruminal protein. Indeed, the observed reduction in CP digestibility (Table 3) by inclusion of PPE-treated RPB confirms these results. Consistent with these results, Jolazadeh et al. (2015) reported that ruminal ammonia-N concentration of Holstein bulls decreased when they were fed soybean meal treated with pistachio extract concentrate.

As expected, the reduction of ruminal ammonia-N concentration in lambs consuming RBP treated with PPE was accompanied by lower blood urea and BUN contents (Table 4). Indeed, Azizi-Shotorkhoft et al. (2012) observed a positive correlation between ruminal ammonia- $\mathrm{N}$ and BUN concentrations 
Table 7 Effect of feeding recycled poultry bedding treated with different levels of pomegranate peel extract on carcass characteristics of male Arabi lambs

\begin{tabular}{|c|c|c|c|c|c|c|}
\hline & \multicolumn{4}{|c|}{ Level of treated $\mathrm{RPB}^{1}$} & \multirow{2}{*}{ SEM } & \multirow{2}{*}{$P$-value } \\
\hline & 0 & 20 & 25 & 30 & & \\
\hline \multicolumn{7}{|l|}{ Harvesting data } \\
\hline Empty bodyweight, kg & 29.2 & 30.2 & 32.3 & 28.8 & 1.22 & 0.25 \\
\hline Warm carcass weight, $\mathrm{kg}$ & $17.5^{\mathrm{b}}$ & $17.8^{\mathrm{b}}$ & $18.8^{\mathrm{a}}$ & $17.4^{\mathrm{b}}$ & 0.43 & 0.04 \\
\hline Dressing percentage, \% & 52.1 & 51.9 & 51.8 & 52.5 & 1.85 & 0.57 \\
\hline Digestive contents, kg & 3.4 & 3.0 & 3.1 & 3.2 & 0.42 & 0.94 \\
\hline Empty digestive tract, $\mathrm{kg}$ & 3.1 & 3.5 & 3.3 & 3.1 & 0.29 & 0.74 \\
\hline Empty rumen, kg & 0.63 & 0.62 & 0.72 & 0.60 & 0.050 & 0.38 \\
\hline Back-fat thickness, mm & 7.1 & 7.3 & 7.0 & 7.0 & 0.34 & 0.74 \\
\hline \multicolumn{7}{|l|}{ Carcass components } \\
\hline Neck $(\mathrm{kg})$ & 0.74 & 0.73 & 0.77 & 0.73 & 0.034 & 0.83 \\
\hline Shoulder (kg) & 2.87 & 2.96 & 3.36 & 2.96 & 0.20 & 0.37 \\
\hline Brisket (kg) & 3.76 & 4.09 & 4.43 & 3.87 & 0.19 & 0.12 \\
\hline Loin (kg) & 2.24 & 2.52 & 2.19 & 2.38 & 0.14 & 0.34 \\
\hline Leg & 4.88 & 4.96 & 5.23 & 4.85 & 0.12 & 0.16 \\
\hline Tail $(\mathrm{kg})$ & 1.58 & 1.72 & 1.79 & 1.56 & 0.08 & 0.16 \\
\hline \multicolumn{7}{|l|}{ Other components } \\
\hline Skin $(k g)$ & 4.81 & 5.41 & 5.61 & 5.11 & 0.44 & 0.16 \\
\hline Head (kg) & 1.48 & 1.64 & 1.81 & 1.62 & 0.09 & 0.17 \\
\hline Feet & 1.07 & 0.83 & 0.90 & 0.82 & 0.082 & 0.19 \\
\hline Internal fat (kg) & 0.22 & 0.24 & 0.21 & 0.24 & 0.019 & 0.58 \\
\hline Liver (kg) & 0.62 & 0.61 & 0.67 & 0.59 & 0.05 & 0.13 \\
\hline Lung (kg) & 0.39 & 0.40 & 0.42 & 0.36 & 0.019 & 0.27 \\
\hline Heart (kg) & 0.12 & 0.16 & 0.18 & 0.15 & 0.018 & 0.23 \\
\hline Kidney (kg) & 0.12 & 0.11 & 0.13 & 0.13 & 0.012 & 0.66 \\
\hline Spleen (kg) & 0.047 & 0.053 & 0.060 & 0.047 & 0.008 & 0.57 \\
\hline Testicles (kg) & 0.12 & 0.14 & 0.12 & 0.11 & 0.009 & 0.24 \\
\hline
\end{tabular}

RPB: recycled poultry bedding

${ }^{1}$ RPB treated with pomegranate peel extract at the levels of $0 \%$ (control), $20 \%, 25 \%$, and $30 \%$ of DM SEM: standard error of mean

a,b Means within a row with different superscripts differ significantly $(P<0.05)$

Table 8 Effect of feeding recycled poultry bedding treated with different levels of pomegranate peel extract on economic analysis of male Arabi lambs

\begin{tabular}{lccccccc}
\hline & \multicolumn{9}{c}{ Level of treated RPB } & \multirow{2}{*}{ SEM } & $P$-value \\
\cline { 2 - 5 } & 0 & 20 & 25 & 30 & & \\
\hline Price of each kilogram diet $^{1}$ & 0.257 & 0.230 & 0.228 & 0.224 & - & - \\
Price of each kilogram body weight $^{1}$ & 0.394 & 0.394 & 0.394 & 0.394 & - & - \\
Return on investment $_{\text {Cost per unit of production }}$ & $1.39^{\mathrm{c}}$ & $1.25^{\mathrm{c}}$ & $2.06^{\mathrm{a}}$ & $1.66^{\mathrm{b}}$ & 0.028 & 0.01 \\
& $0.717^{\mathrm{b}}$ & $0.798^{\mathrm{a}}$ & $0.485^{\mathrm{d}}$ & $0.603^{\mathrm{c}}$ & 0.002 & 0.01 \\
\hline
\end{tabular}

RPB: recycled poultry bedding

${ }^{1}$ All costs in US dollar at the moment of conducting the experiment.

$\mathrm{a}, \mathrm{b}, \mathrm{c}, \mathrm{d}$ Means within a row with different superscripts differ significantly $(P<0.05)$ 
Decreasing urea and BUN concentrations in lambs fed diets containing PPE could not change albumin and total protein concentrations in the plasma of those fed the former diets. The reduction of BUN may be due to decreased ruminal proteolysis and a decline in ammonia production and reduced absorption of ruminal ammonia to blood (Abarghuei et al., 2014). Glucose and triglyceride concentrations in plasma were unchanged by experimental diets, probably because DMI was similar among experimental lambs. Results from the current study confirm the findings by Jolazadeh et al. (2015), who indicated that treatment of soybean meal with various levels of pistachio extract concentrate did not affect the concentrations of glucose and triglyceride in Holstein bulls. Additionally, Abarghuei et al. (2014) reported that blood glucose, albumin and triglyceride concentrations were not changed by supplementing dairy cow diets with PPE, although blood BUN decreased linearly rumen liquor with added PPE. Contrary to the current results, Makkar (2003) found that condensed tannin increased the molar proportion of propionate, a glucogenic precursor that is formed in the rumen, which may increase the concentration of plasma glucose.

The higher $N$ retention observed in lambs fed RPB treated with 25\% PPE compared with those fed with RPB that was free of PPE (without tannin) may be attributed to protecting dietary protein from ruminal degradation, and shifting its digestion and absorption to the small intestine. The increase in urinary $\mathrm{N}$ excretion (Table 5) and lower ruminal ammonia-N (Table 4) when feeding RPB treated with PPE confirm these results. Another possible explanation is a better optimization of rumen fermentation through the gradual release of the NPN in RPB treated with PPE. The greatest part of NPN content of RPB is in the form of uric acid, and the formation of uric acid-tannins complexes is possible. Binding between tannins and proteins is largely by hydrogen bond formation between the phenolic hydroxyl groups of the tannins and the carbonyl groups of the proteins (Harumen liquorey et al., 2017). Azizi-Shotorkhoft et al. (2012) also reported that optimizing the rate of degrading the CP content of RPB decreased ruminal ammonia- $\mathrm{N}$ improved microbial protein synthesis. In agreement with the current results, Aguerre et al. (2016) observed an improvement in retained $\mathrm{N}$ in dairy cows fed quebracho-chestnut tannin compared with a control diet. They illustrated that the improvement in $\mathrm{N}$ balance in sheep fed tannins was due to increased recycling of $\mathrm{N}$ from the blood to the rumen, which more than compensated for some faecal $\mathrm{N}$ loss in these diets. However, in the study of Rahimi et al. (2014), N retention was unaffected by replacing various levels of alfalfa with pistachio hull in the diet of Balochi male lambs.

In the present study, because DMI was unchanged among the experimental diets, this was probably related to the relatively similar chemical composition and physical form of the diets, because the composition and physical characteristics of feed affect feed intake (Karimizade et al., 2017). Consistent with the current results, in the study of Jolazadeh et al. (2015) with Holstein bulls, the treatment of soybean meal as a protein supplement with various levels of pistachio extract concentrate as a tannin source did not affect DMI.

Despite similar DMI among experimental diets, the level of $25 \%$ tannin supplementation improved lamb performance. The increased FBW, TG and ADG in lambs fed RPB treated with 25\% PPE compared with the others was probably due to an increased amino acid flow to the duodenum, and consequently higher retained N. Jolazadeh et al. (2015) also reported increased ADG and feed efficiency in Holstein bulls fed soybean meal treated with increasing levels of pistachio extract concentrate.

Increased HCW in lambs fed diets containing 25\% PPE compared with those fed 30\% PPE may have been due to higher FBW and N retention in the 25\% PPE treatment. The numerically greater carcass cuts in lambs fed RPB treated with 25\% PPE was also associated with their better FBW (Hailu et al., 2011).

The highest return on investment and lowest cost per unit production were obtained in the diet containing $25 \%$ tannin extract, which indicating better economic value of the diet containing $25 \%$ tannin extract.

\section{Conclusions}

According to the current results, the treatment of RPB with 25\% PPE as a source of phenolic materials and tannin in the diet of lambs as an inexpensive protein source, had the best results, and improved FBW, total gain, ADG and economic value of diets and meat production. This treatment increased the retention of $\mathrm{N}$, decreased nitrogen excretions, and improved $\mathrm{N}$ metabolism.

\section{Acknowledgements}

The authors are grateful to Agricultural Sciences and Natural Resources University of Khuzestan for support of this experiment.

\section{Authors' Contributions}

All authors were responsible for designing the research, implementing it, and writing the manuscript.

\section{Conflict of Interest Declaration}

There are no conflicts of interest. 


\section{References}

Abarghuei, M.J., Rouzbehan, Y., Salem, A.Z.M. \& Zamiri, M.J., 2014. Nitrogen balance, blood metabolites and milk fatty acid composition of dairy cows fed pomegranate-peel extract. Livest. Sci. 164, 72-80.

Aguerre, M.J., Capozzolo, M.C., Lencioni, P. Cabral, C. \& Wattiaux, M.A. 2016. Effect of quebracho-chestnut tannin extracts at 2 dietary crude protein levels on performance, rumen fermentation, and nitrogen partitioning in dairy cows. J. Dairy Sci. 99, 4476-4486.

Alipour, D. \& Rouzbehan, Y., 2010. Effects of several levels of extracted tannin from grape pomace on intestinal digestibility of soyabean meal. Livest. Sci. 128, 87-91.

Anderson, R.V., Rasby, R.J., Klopfenstein, T.J., Clark, R.T., 2005. An evaluation of production and economic efficiency of two beef systems from calving to slaughter. J. Anim. Sci. 83, 694-704.

Animut, G., Merkel, R.C., Abebe, G., Sahlu, T. \& Goetsch, A.L., 2002. Effects of level of broiler litter in diets containing wheat straw on performance of Alpine doelings. Small Rumin. Res. 44, 125-133.

AOAC, 1990. Official Methods of Analysis (15th ed.) Association of Official Analytical Chemists, Arumen liquorington, VA, Washington, DC., USA.

AOAC, 2005. Official Methods of Analysis (18th ed.) Association of Official Analytical Chemists, Arumen liquorington, VA, Washington, DC, USA.

Azizi-Shotorkhoft, A., Rouzbehan, Y. \& Fazaeli, H., 2012. The influence of the different carbohydrate sources on utilization efficiency of processed broiler litter in sheep. Livest. Sci. 148, 249-254.

Azizi-Shotorkhoft, A., Rezaei, J., Papi, N., Mirmohammadi, D. \& Fazaeli, H., 2015. Effect of feeding heat-processed broiler litter in pellet-form diet on the performance of fattening lambs. J. Appl. Anim. Res. 43, 184-190.

Badiee Baghsiah, M., 2011. Effect of heat processing on the nutritive value and population count of some pathogenic bacteria of broiler litter. MSc thesis. Tarbiat Modares University of Tehran, Tehran, Iran.

Broderick, G. \& Kang, J.H., 1980. Automated simultaneous determination of ammonia and total amino acids in ruminal fluid and in vitro media. J. Dairy Sci. 54, 1176-1183.

Capparucci, C., Gironi, F. \& Piemonte, V., 2011. Tannins extraction from walnuts residues. Chem. Engineer. Trans. 24, 469-474.

Dentinho, M., Moreira, O., Pereira, M. \& Bessa, R., 2007. The use of a tannin crude extract from Cistus ladanifer L. to protect soya-bean protein from degradation in the rumen. Animal 1,645-650.

Dschaak, C.M., Williams, C.M., Holt, M.S., Eun, J.S., Young, A.J. \& Min, B.R., 2011. Effects of supplementing condensed tannin extract on intake, digestion, ruminal fermentation, and milk production of lactating dairy cows. J. Dairy Sci. 94, 2508-2519.

FASS, 2010. Guide for the Care and Use of Agricultural Animals in Research and Teaching, 3rd ed. Federation of Animal Science Societies, Champaign, IL., USA.

Givens, D.I., Owen, E., Axford, R.F.E. \& Omed, H.M., 2000. Forage evaluation in ruminant nutrition. 1st ed. CABI, Wallingford, UK. $480 \mathrm{pp}$.

Griswold, K.E., Apgar, G.A. \& Bouton, J., 2003. Effects of urea infusion and ruminal degradable protein concentration on microbial growth, digestibility, and fermentation in continuous culture. J. Anim. Sci. 81, 329-336.

Hailu, A., Melaku, S., Tamir, B. \& Tassew, A., 2011. Body weight and carcass characteristics of Washera sheep fed urea treated rice straw supplemented with graded levels of concentrate mix. Livest. Res. Rural Dev. 23 (8)

Harley, D., Naumann, L.O., Tedeschi, W.E. \& Zeller, N.F.H. 2017. The role of condensed tannins in ruminant animal production: advances, limitations and future directions. R. Bras. Zootec. 46 (12), 929-949.

Jasmin, B.H., Boston, R.C., Modesto, R.B. \& Schaer, T.P., 2011. Perioperative ruminal pH changes in domestic sheep (Ovis aries) housed in a biomedical research setting. J. Am. Assoc. Lab Anim. Sci. 50 (1), 27-32.

Jolazadeh, A.R., Dehghan-banadaky, M. \& Rezayazdi, K., 2015. Effects of soyabean meal treated with tannins extracted from pistachio hulls on performance, ruminal fermentation, blood metabolites and nutrient digestion of Holstein bulls. Anim. Feed Sci. Technol. 203, 33-40.

Karimizadeh, E., Chaji, M. \& Mohammadabadi T., 2017. Effects of physical form of diet on nutrient digestibility, rumen fermentation, rumination, growth performance and protozoa population of finishing lambs. Anim. Nutr. 3, 139-144.

Kyanzad, M.R., 2001. Crossbreeding of the three Iranian sheep breeds with emphasis on growth and carcass characteristics of the lambs. PhD thesis, University of Utra, Malaysia.

Makkar, H.P.S., 2000. Quantification of tannin tree and shrub foliage. A laboratory manual for the FAO/IAEA coordinated research project on use of nuclear and related techniques to develop simple tannin assays for predicting and improving the safety and efficiency of feeding ruminants on tanniniferous tree foliage. In: Joint FAO/IAEA of Nuclear Techniques in Food and Agriculture. Animal Production and Health Sub-Programme, FAO/IAEA Working Document. IAEA, Vienna, Austria.

Makkar, H.P.S., 2003. Effects and fate tannins in ruminant animals, adaptation to tannins, and strategies to overcome detrimental effects of feeding tannin-rich feeds. Small Rumin. Res. 49, 241-256.

Mavimbela, D.T. \& Van Ryssen, J.B.J., 2001. Effect of dietary molasses on the site and extent of digestion of nutrients in sheep fed broiler litter. S. Afr. J. Anim. Sci. 31, 33-39.

McAllister, T.A., Bae, H.D., Jones, G.A. \& Cheng, K.J., 1994. Microbial attachment and feed digestion in the rumen. J. Anim. Sci. 72, 3004-3018.

Min, B., Barry, T., Attwood, G. \& McNabb, W., 2003. The effect of condensed tannins on the nutrition and health of ruminants fed fresh temperate forages: A review. Anim. Feed Sci. Technol. 106, 3-19.

Mirzaei-Aghsaghali, A., Maheri-Sis, N., Mansouri, H., Razeghi, M.E., Mirza-Aghazadeh, A., Cheraghi, H. \& Aghajanzadeh-Golshani, A., 2011. Evaluating potential nutritive value of pomegranate processing byproducts for ruminants using in vitro gas production technique. J. Agri. Biol. Sci. 6, 45-51. 
National Research Council (NRC), 2007. Nutrient requirements of small ruminants, sheep, goats, cervide and new word camelids. National Academy of Science, Washington, DC., USA.

Obeidat, B.S., Awawdeh, M.S., Abdullah, A.Y., Muwalla, M.M., Abu Ishmais, M.A. \& Telfah, BT., 2011. Effect of feeding broiler litter on performance of Awassi lambs fed finishing diets. Anim. Feed Sci. Technol. 165, 15-22.

Patra, A.K. \& Saxena, J., 2011. Exploitation of dietary tannins to improve rumen metabolism and ruminant nutrition. J. Sci. Food Agri. 91, 24-37.

Rahimi, A., Naserian, A.A., Valizadeh, R., Tahmasebi, A.M. \& Shahdadi, A.R., 2014. Effects of replacing different levels of alfalfa hay with Pistachio hull on feed intake, digestibility of nutrients, rumen fermentative parameters, blood metabolites and nitrogen balance in Balochi male lambs. Iranian J. Anim. Sci. Res. 6 (3), 227-238.

Rankins, D.L., Poore, M.H., Capucille, D.J. \& Rogers, G.M., 2002. Recycled poultry bedding as cattle feed. Clin. North Am. Food Anim. Pract. 18, 253-266.

Robertson, J.B. \& Van Soest, P.J., 1981. The detergent system of analysis and its application to human foods. In: W.P.T. James \& O. Theander (eds.). The Analysis of Dietary Fibre in Food. Marcel Dekker, NY, USA, pp. 123-158 (chapter 9).

SAS, 2001. Statistical Analysis Systems. User's guide. Version 8.2. SAS Institute, Cary, NC, USA.

Sharifi, A., Chaji, M. \& Vakili, A.R., 2017. Effect of processing broiler litter with phenolic compounds extracted from pomegranate peel on gas production parameters, rumen fermentation, nutrient digestibility and rumen fungi and bacteria growth. J. Anim. Prod. (in Persian).

Statistical Centre of Iran, 2013. Selected Census Results of the Broiler Chicken Farms, the Year 1391 (March/21/2012 to March/20/2013). Vice-Presidency for Strategic Planning \& Supervision, Statistical Centre of Iran, 34.

Tamminga, S. \& Hobson, P.N., 1996. A review on environmental impacts of nutritional strategies in ruminants. J. Anim. Sci. 74, 3112-3124.

Van Soest, P.J., Robertson, J.B. \& Lewis, B.A., 1991. Methods for dietary fibre, neutral detergent fibre and non starch polysaccharides in relation to animal nutrition. J. Dairy Sci. 74, 3583-3597. 